\title{
The role of ethical leadership in increasing employees' organizational commitment and performance: the case of healthcare professionals
}

\author{
Gülay Tamer ${ }^{1}$ D \\ 1 Assist. Prof. Dr. İstanbul Gelişim University, Faculty of Health Science, Department, İstanbul, TURKEY, E-mail: gtamer@gelisim.edu.tr
}

\begin{abstract}
Today's organizations are looking for ways to improve the organizational commitment and performance of employees in order to have a qualified workforce and maintain sustainability. Organizational leaders' approach to increasing employee motivation positively affects their organizational commitment and job performance. This research, basically focusing on the health sector, tried to specify the effect of the managers' ethical approach on employees' organizational commitments, performances, and the role of organizational commitments in this effect. The sampling was composed of 362 healthcare professionals. In this cross-sectional field study, an independent variable model for the ethical leadership approaches and a dependent variable model for the employees' performance and commitment to their organizations were practiced. Data was collected through Ethical leadership, Organizational Commitment, and Individual Performance Scales. The data collected were analyzed through SPSS and AMOS package programs. A correlation analysis to specify the relationships between the variables and a regression analysis was done to specify the interaction. In specifying the intermediary role of organizational commitment, Structural Equation Model (SEM) was used. The results of the analyses showed positive significant relationships between ethical leadership approaches and organizational commitment and employees' performance. It was also observed that ethical leadership approaches had a positive and meaningful effect on affective, continuous and normative commitment, the sub-dimensions of organizational commitment, as well as the employees' performance. On other important finding is employees' attendance and normative commitment are highly affected by ethical leadership approaches.
\end{abstract}

As a result, it was specified that ethical leadership approaches by the managers are highly effective on employees' performance and their commitment. It was also noted that organizational commitment played a mediator role on ethical leadership approaches. These findings were seen to be amicable with findings in previous studies. It is expected that this research will contribute to the literature because it is a holistic model including the relationships between variables.

Keywords: Organizational Commitment, Employee Motivation, Ethical Leadership, Performance. Manager.

JEL codes: M1, M12.

Citation/Atıf: TAMER, G. (2021). The Role of Ethical Leadership in Increasing Employees' Organizational Commitment and Performance: The Case of Healthcare Professionals. Journal of Life Economics. 8(1), 123-146, DOI: 10.15637/jlecon.8.1.13

Corresponding Author/ Sorumlu Yazar: Gülay Tamer

E-mail: gtamer@gelisim.edu.tr
Bu derginin içeriği Creative Commons Attribution-NonCommercial 4.0 Uluslararası Lisansı altında lisanslanmıştır.

Content of this journal is licensed under a Creative Commons Attribution-NonCommercial 4.0 International License. 


\section{INTRODUCTION}

Increasing competitiveness on the world has led organizations to look for new methods to achieve their aims. In this respect, the perception of ethical leadership for firms has become one of the crucial concepts. Ethical leadership approaches and productivity of the workers have become important factors in the success and continuity of the organizations. For organizational success, ethical rules should not be ignored, and positive approaches should be exhibited to increase employees' motivation, their commitments, trust and performance. Modern business world approves the idea that an effective ethical climate in organizations is of crucial importance and need.

\section{LITERATURE REVIEW}

Ethic is a set of values composed of sociological rules guiding individuals' behavior and, explaining behavioral styles approved by the people and society. In terms of morality, it is a system of specified principles and rules provided by the community explaining approved and disapproved behaviors. Ethical rules specify adapted good and bad principles approved by the community. These principles lead an individual in avoiding unwanted cases and shape his/her everyday behaviors (Fletcher, 1996:3).Meeting the expectations of working people and the needs of the community is possible only through following developments and changes and the leaders' commitments in fulfilling the requirements of ethical values (Sigler, Pearson ,2000).

Organizational ethics deals with what are wrong and right as well as social and moral responsibilities (Piccolo, R. F. Greenbaum, R.H., Hartog D.N., Folger, R. 2010:). Ethical rules play a crucial role in the formation of principles and norms for the betterment of manager- worker relationships (Avolio, B.J. and Bass, B.M. 1995). Ethical approaches in organizations make that managers and leaders to be fair and honest, behave properly, and account for when required (Cummings L.L. , Schwab D.P,1973). It is obvious that the servants, clients and others involved have more expectations from their managers' ethical approaches (Velasquez,2002: 2).

People in managerial positions have started considering value factors, therefore, their ethical behaviors have come into prominence. It is stated that one of the ways for the managers to raise the performance and organizational commitments of their employees is their ethical approaches (Harman,1999). In addition, ethical leadership is the best tool in creating a democratic environment between individuals and organizations (Held,2006).Theirs is a strong connection between ethical and effective leadership. In the definition of ethical leadership concept, ethical values such as honesty and fairness, behavioral and personality, were the first steps considered. Leaders should have ethical values and thoughts and the organizational activities should go through ethical filters .Today, leaders valuing individuals, emotions, trust, and beliefs are needed rather than the ones making use of their positions and authorities (Ciulla, 1996:112). Some researchers assume ethical leadership as the center of leadership, and a requirement for organizational activities, productivity and effectiveness (Fulmer, 20004: 313).At this point, ethical leadership can be defined as a leadership developing ethical codes, struggling for favors, respecting others, being honest, reliable, friendly, able to set relationships with different individuals, being democratic in making decisions and behaviors, supporting participation in management, being kind and thoughtful, and keeping all ethical values together and reflecting them to activities (Mihelic, Lipicnic, Tekavcic, 2013:109).

The ones known as ethical leaders are the ones who take on ethical responsibilities and requirements in terms of individual or organizational views (Y1lmaz, 2005:44; Hermond, 2005:14). Ethical leaders are the ones who know what is correct, with a balanced personality, advocating values and beliefs, putting together moral, motivation and power in self-personality. They oppose to misbehaviors and approaches and put an end when requiered. They can cancel decisions if they notice any ethical problems in them (Bennis, 2009: 138).Exhibiting ethical behaviors make the workers see them as model behaviors, which will become a part of the organization (Lesinger, Altınay , Dağll, 2017) and thus, the workers will be satisfied and this will end in higher performance and organizational commitment (Mayer, Kuenzi, Greenbaum, Bardes, Salvador, 2009: 2-5).Ethical leadership is composed of four dimensions; communicative, climatic, behavioral, and organizational decision making

\subsection{Communicative Ethics}

Communication is defined as the process of generating knowledge, conveying, and making it meaningful (Douglas, 2005). In order to sustain existence, individuals and communities have to form a sound communication. The success of ethical leadership approaches depends on providing an effective 
communication environment and their communicating skills in time and in a suitable manner. Therefore, the communication between managers and their staff should be proper and consistent. Managers who are successful in this issue raise success and performance and consolidate organizational commitment (Sikander,2010). This is an indication that workers are on the right in terms of their needs for information. Therefore, managers are responsible for passing on the correct information. Communication within ethical principles and rules forms a warm environment between managers and their staff (Ferrell, Maignan,_Loe, 1999). Otherwise, ill communication will cause clashes and lessen both performance and commitment to the organization. At this point, it is vital that, besides possessing ethical values, leaders should reflect this to the staff (Bennis, 2009: 64).

\subsection{Climatic Ethics}

An organization has a structure peculiar to itself and this forms its Climatic source. Organizational climate deals with the relationship among the staff reflects values, principles and applications and leads the staff in their behaviors. Managers and leaders are the keys of organizational climate and influence it by their behaviors and decisions (Varol, 1989: 217-222). If managers and leaders possess climatic ethical understanding, they are reliable, honest and friendly. In addition, possessing climatic ethics requires vision, participation, and encouraging the staff (Aydoğan, 2004: 211-214). A health climatic organization takes on a role to increase employees' performance and their organizational commitments. The importance of ethical leadership in the eyes of the workers is the leader's effort in supporting development, balancing the conditions and creating a developing climate (Toor, Ofori, 2009: 2-4).

\subsection{Ethics in Making Organizational Decisions}

Decision making is a crucial issue in human life. It represents the process which is essential to sustain life till the end. Life is a chain of making decisions which indicates the vitality of the process Decision making is als o an important managerial factor (Fulmer,2005). Managers should make their decisions responding to ethical values (Akdemir,2012). When administrators make decisions, they have to consider all alternatives, standards, rules and regulations, and the values of the community the organization belongs to. Managers who adapt ethical values, help to create an organizational climate and prevent the workers from leaving the organization (Freeman,Steward,2006).

\subsection{Behavioral Ethics}

Managers consider several different factors in the process of their managerial position. Being in favors of the staff, meeting their needs and demands, distributing tasks equally to achieve success in the organization are some of the factors. The staff in an organization expects their managers to be egalitarian, honest, possess moral sense, and ethical behaviors (Gümüşeli, 2001:543-545). Managers' exhibit their ethical behaviors by being reliable, honest, courageous, kind, generous, and self-sacrificing. They are expected to be devoted to their professions, understanding, and respectful to different beliefs and opinions (Kılınç, 2010:33).Managers exhibiting ethical behaviors and caring for employees' needs, being fair and equal treating, help develop organizational commitments (Toor , Ofori, 2009:2-4). Organizations which adapted ethical behaviors and practiced them in daily life, show that they have understood the importance of ethical management (Mayer, Aquino, Greenbaum ,Kuenzi, 2012: 164-167). As a result, ethical leadership approaches require both exhibiting ethical leadership behaviors and supporting work-mates. Managers and leaders with honesty and fairness and making right decisions in time will bring success for themselves, for the leadersand for the organizations (Ferrell, Maignan, Loe,1999).

\subsection{Organizational Commitment}

Equality, a concept frequently used in daily life, reminds commitment, being emotional towards someone love and respect (KirkmanB.L.,RosenB.1999).Beyond Self-Management: Antecedents and Consequences of Team Empowerment. The Academy of Management Journal, Commitment is defined as the top level feeling existing in every part of the community and individuals' commitment to their outstanding things rather than their own self. In terms of organizations, it is defined as the feeling of identity and unity its members. For organizational sustainability, the staff should not leave the organization. Their level of commitment is one of the factors indicating the power of the organization. This is why there are efforts to create a strong commitment between organizations and their staff (Mathieu, Zajac, 1990: 171-171).

In a broad sense, organizational commitment is the feeling ofbeing dependent and constant members (Wallace, 1995). Organizational commitment can also be defined as an individual's feeling of identity and participation in the life-span of the organization 
(Hartline, Maxam \& McKee, 2000:40).Luthans (1992:130) explains organizational commitment as its members" commitment and devotion to their organization. Robbins, on the other hand, defines it as the members' identifying themselves with the aims of the organization and wishing to sustain this identity (Robbins, 2002:143). Organizational commitment is a positive indication in terms of an organization There are three crucial factors in organizational commitment. These are: acknowledging and believing in the aims of the organization, wish and desire to work for it (Tett, Meyer, 1993:259-261). In other words, there are three phases in commitment; involvement, developing identity, and complying with it Meyer and Allan explains it as the members' seeing themselves as a part of it, keeping their aims in harmony and in unity, looking at events through the same angle and heading for the same aims. Meyer \& Allan (1991:61) added saying that organizational commitment had three dimensions; affective, normative and continuous. Affective Commitments establishing an affective bind with the organization, Continuous Commitment is compulsory attendance, and Normative Commitment is the ethical responsibility to stay with the organization, but not to leave (Meyer, Allen, 1991: 61).The bind between the organization and its members plays a big role in stopping members from leaving the organization and making them accept negative situations. As for Continuous Commitment, the members do not want to leave the organization, because they avoid facing any inconveniency after leaving. They can't dare this as they think it may turn into a difficult situation (Cummings, Schwab ,1973). In Normative Commitment the members are grateful to the organization for the advantages provided and they consider it ethical to stay with the organization and try to answer for what they are provided with. Commitment in any way is to keep the members within the organization. However, the perception of commitment differs among members (O' reilly, Chatman, 1986:492). Although different definitions have been done, it is commonly agree that there basically it is a psychological situation. As a result, organizational commitment is assumed as a perception of keeping the members in the organization and shaping relationships between them and the organization (Meyer, Allen, 1997:11).

\subsection{Performance}

Performance and performance management is one of the most complicated and arguable issues. In terms of management, performance is the ability to explain all the obtained numeric or nonnumeric data (Akçakanat, 2009:4). Morillo (1990:270) defines performance as the success of the tasks assigned to individuals. While success is defined as reaching at targeted aims, performance is defined as the total effort in reaching these aims or tasks. Performance indicates the process, whereas success indicates the result (Churin, 2006: 3).The performance of an organization is considered in two dimensions, individual and organizational ( Zhu, May, Avolio, 2004). Individual performance is an individual's ability in reaching a result qualitatively and quantitatively as required (Shields, 2007: 21, Özpehlivan, 2015:136). Individual performance indicates an individual's success rate(McGrath, 1995:251). While individual performance evaluates one's success in the organization, organizational performance evaluates property, service, and the profit ( Cummings .Schwab ,1973 ). Sustainability of organizational success is possible with the harmony between organizational and individual performance. It is assumed that, if there is harmony, there is no doubt that both performances will increase (Watson,2010).

Performance is an important issue for managers. The level of the performance exhibited by the staff equally affects the performance of that organization. For this reason, one of the basic responsibilities of managers is to develop and increase the performance of the staff. It is one of the basic responsibilities of the managers to take measures to develop employees performance (Aktaş, 2015: 3-7; Kennerley , Neely, 2002: 122-127). Performance evaluation is significant for workers. They want to work for managers who appreciate what they do and are aware of their abilities (Katerberg, 1983:250). Therefore, managers should watch the employees efforts, award them and meet their expectations (Zhu, W., Chew, I., Spangler, W. 2005). Workers doing their job as expected do not want to be evaluated in the same category with the ones who fail to do so. Otherwise, they will be demotivated and demoralized. Evaluating performance on the right basis motivates the worker as well as adds to their organizational commitment (Cohen, 1992: 192). Raising performance in enterprises is one of the crucial issues managers should consider. It should never be ignored in the managerial system. Managers need to 
assess employees' performance at times and inform them on the outcomes. They should not ignore such an expectation by the workers ( Wasti, 2000). If done as expected, will add to both the performance of the organization and the workers. Individuals working in health sectors are dispersed and evaluating them by seniors is both costly and difficult. Therefore, self-evaluation method is practiced (Bose, Oliveras,Edson, 2001:3). In this respect, performance evaluation on the basis of self-evaluation is assumed a similar method activating other cognitive, affective and behavioral mechanisms, used in other evaluation (McKennerley, M. ,Neely, A. 2002). In this study, performance evaluation method, based on self-evaluation, was approached. Failure in the observation of the employees' levels of commitment to their organizations, leads to self-evaluation ( Piccolo.et.all, 2010).

\section{AIM OF THE RESEARCH}

The aim of this research was to specify the effect of the managers', in private health sectors, ethical leadership approaches on the performance and organizational commitments of their staff as well as to specify the intermediary role of organizational commitment.700 health professionals (managers, doctors, nurses, clerks, servants, and administrative staff) from private health institutions in Beşiktaş, İstanbul. 362 questionnaires were analyzed. The sampling size in this research is $\% 48.8$

\section{METHODOLOGY}

In this study, it is aimed to determine the effects of ethical leadership approaches exhibited by the managers of private health institutions on the organizational commitment and performance of healthcare professionals and to examine the effects of ethical leadership approaches on organizational commitment and performance. All data are statistically analyzed using some package programs was kept. Display of continuous data is median (minimum - maximum) and (mean \pm standard deviation). Compliance of data to normal distribution ShapiroIt was tested with the Wilk Test.

Between means for continuous data in the test result Mann - Whitney U Test and Kruskal Wallis tests were used for comparisons. The relationship between continuous variables was analyzed using the Spearman correlation coefficient. The reasons for the relationships between variables can be determined by Multiple Linear Regression Analysis.It has been investigated. The statistical significance level was determined as $\mathrm{p}<0.05$.

\subsection{Data Gathering, Method and Tools}

In this cross-sectional field study, three scales were used to collect data. Ethical Leadership Scale as developed by Brown, Trevino ,Harrison (2005) and was adapted into Turkish by Tuma, Bircan ,Yeşiltaş (2012). The scale is composed of four dimensions; Communicative Ethic, Climatic Ethic, Behavioral Ethic, and Organizational decision-making Ethic. The organizational Commitment scale was developed by Allen, Meyer (1990) and was adapted into Turkish by Wasti (2000). The scale consists of three dimensions; Affective commitment, Continuous Commitment, and Normative Commitment. An Individual Performance Scale, developed by Kirkman, Rosen (1999), used by Sigler ,Pearson (2000), and adapted into Turkish by Çöl (2008) was administered. At the of the measurements, Cronbach's Alpha efficiency was found as 0.91, the performance scale was 0.83 , and organizational commitment scale was 0.85. The Cronbach Alpha values of all the efficiencies reached are at acceptable levels.

\subsection{Research Model and Hypotheses}

A model was formed to specify the connection among variables in the scope of the research. The models and hypotheses are as follows (see Fig.1);

H1. There is a significant connection between the managers' ethical approaches and the employees performance

H2. There is a significant connection between the managers' ethical approaches and the employees organizational commitment.

H3. There is a significant effect of the managers' ethical leadership approaches on employees performance

H4. There is a significant effect of the managers' ethical approaches on employees organizational commitment

H5. There is a mediation role of the managers' ethical leadership approaches on employees performance 


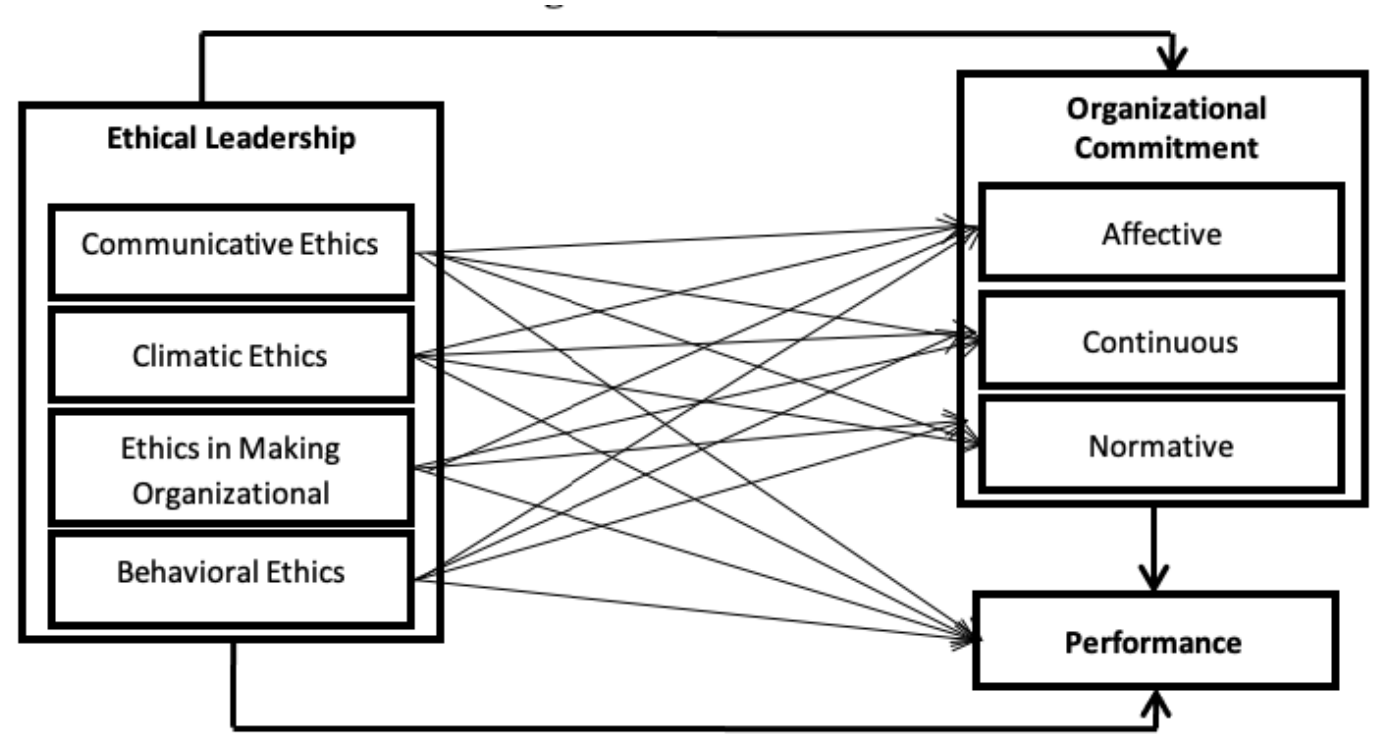

\subsection{Data Analysis}

The connection among the continuant variables was investigated through Spearman Correlation efficiency and the reason for the connections among the variables was examined through multi-linear regression analysis. In order to test the structural validity, a confirmatory factor analysis was done. At the end of this analysis, Q5 from ethical subdimension, Qs 3,4, and 6 from Affective commitment and Qs 1 and 2 from Normative commitment were omitted because these questions did not fit the validity in decision making. For structural model, the confirmatory factor analysis and compliance values were overviewed it was determined that the compliance model was applicable Prior to structural equality model, multi-normative assumption and multi-connection hypothesis were controlled for any possible problems. A system analysis with Structural Equality Model was done to specify mutual relationships among variables and the role of organizational commitment on the direct and indirect and ethical leadership approaches. The compliance values to structural equality model and compliance intervals are presented in Table 1. The data were analyzed through SPSS and AMOS programs.

Table 1. Values of the Structural Equation Model

\begin{tabular}{|l|c|c|}
\hline \multicolumn{1}{|c|}{ Compliance statistic } & Good compliance & Acceptable compliance \\
\hline c2 compliance test & $0.05<\mathrm{p} \leq 1$ & $0.01<\mathrm{p} \leq 0.05$ \\
\hline (c2/sd) & $\leq 3$ & $4-5$ \\
\hline CFI & $\geq 0,90$ & $0,89-0,85$ \\
\hline GFI & $\geq 0,90$ & $0,89-0,85$ \\
\hline RMR & $0<\mathrm{RMR} \leq 0.05$ & $0<\mathrm{RMR} \leq 0.08$ \\
\hline RMSEA & $\leq 0,05$ & $0,06-0,08$ \\
\hline
\end{tabular}

(CFI:Comparative Fit Index, RMSEA: Root Mean Square Error of Approximation, GFI: Goodness Of Fit Index, RME: Root Mean Square Residual

Source: Şimşek, 2007. 
Table 2. Structural Equation Model Analysis

\begin{tabular}{|c|c|c|c|c|c|}
\hline Model & NPAR & CMIN & DF & $\mathbf{P}$ & $\begin{array}{c}\text { CMIN/ } \\
\text { DF }\end{array}$ \\
\hline $\begin{array}{l}\text { Default } \\
\text { model }\end{array}$ & 99 & 2462,410 & 567 & ,000 & 4,343 \\
\hline $\begin{array}{l}\text { Saturated } \\
\text { model }\end{array}$ & 666 & ,000 & 0 & & \\
\hline $\begin{array}{l}\text { Indepen- } \\
\text { dence } \\
\text { model }\end{array}$ & 36 & 8226,604 & 630 & ,000 & 13,058 \\
\hline
\end{tabular}

It was observed that the CMIN/DF value provided $\chi^{2} / \mathrm{sd} \leq 5$ equality. The observed compliance values were in acceptable limits.

\section{FINDINGS}

This part of the research includes the participants' age, gender, education, title, and length of service as well as the findings in correlation analysis, regression analysis and system analysis. The frequency and percentage values of the participants in terms of their demographic characteristics are shown in Table 3.

Table 3. Distribution According to Demographic Characteristics

\begin{tabular}{|c|c|c|c|}
\hline \multicolumn{2}{|c|}{ Demographic Characteristics } & $\mathbf{N}$ & $\%$ \\
\hline \multirow{5}{*}{ Age } & $20-29$ & 48 & 13,3 \\
\hline & $30-39$ & 135 & 37,3 \\
\hline & $40-49$ & 120 & 33,1 \\
\hline & $50-59$ & 51 & 14,1 \\
\hline & $60-+$ & 8 & 2,2 \\
\hline \multirow{2}{*}{ Gender } & Female & 222 & 61,3 \\
\hline & Male & 140 & 38,7 \\
\hline \multirow{6}{*}{ Education } & Primary School & 11 & 3,0 \\
\hline & Secondary School & 96 & 26,5 \\
\hline & High School & 75 & 20,7 \\
\hline & B.A & 50 & 13,8 \\
\hline & Post-Graduate & 28 & 7,7 \\
\hline & Ph.D. & 102 & 28,2 \\
\hline \multirow{5}{*}{ Position } & Manager & 11 & 3,0 \\
\hline & Doctor & 115 & 31,8 \\
\hline & Clerk & 77 & 21,3 \\
\hline & Nurse & 129 & 35,6 \\
\hline & Other & 30 & 8,3 \\
\hline \multirow{4}{*}{ Service time } & $1-5$ yil & 139 & 38,4 \\
\hline & 6-10 yıl & 137 & 37,8 \\
\hline & $11-15$ yil & 77 & 21,3 \\
\hline & $16-20 \mathrm{yil}$ & 9 & 2,5 \\
\hline
\end{tabular}

362 people participated in this research. 222 (\%61.3) were female, 140 (\%38.7) were male, the majority of whom (\%70.4) were between 30-49 years of age. As for their positions and education levels, it was observed that 115 (31.8) were doctors, 129 (\%33.6) were nurses, 77 (\%21.3) were clerks, $11(\% 3)$ were manager, 30 $(\% 8.3)$ were in the other positions. $102(\%$ 28.2) had Ph.D. degrees, 28 (\%7.7) had post-graduate degrees, 70 (\%20.7) had high school diplomas, 50(\%13.8) had B.A degrees, 29 (\%26.5) had secondary school diplomas, and $11(\%)$ had primary school diplomas. As for their length of service in the organization, it is seen that 276 (76.2\%) of them work between 1-10 years.

\subsection{Results of Correlation Analyses}

The correlation values of the variables are as in Table 4 .

Table 4. Correlation Results Amond Dimensions

\begin{tabular}{|c|c|c|c|c|c|c|c|c|c|}
\hline \multicolumn{2}{|c|}{ DIMENSIONS } & 1 & 2 & 3 & 4 & 5 & 6 & 7 & 8 \\
\hline 1 & CE & CLE & ADME & BE & P & AC & CC & NC \\
\hline 2 & 1 & & & & & & & \\
\hline 3 & CLE & $.609^{* *}$ & 1 & & & & & & \\
\hline 4 & ODME & $.421^{* *}$ & $.611^{* *}$ & 1 & & & & & \\
\hline 5 & P & .072 & $.0221^{*}$ & $.641^{* *}$ & 1 & & & & \\
\hline 6 & AC & $.188^{* *}$ & $.343^{* *}$ & $.310^{* *}$ & .039 & 1 & & & \\
\hline 7 & CC & $.247^{* *}$ & .081 & .015 & -.091 & $.163^{* *}$ & $-.516^{* *}$ & 1 & \\
\hline 8 & NC & $.255^{* *}$ & $.359^{* *}$ & $.370^{* *}$ & $.275^{* *}$ & $.112^{* *}$ & $.394^{* *}$ & $-.109^{* *}$ & 1 \\
\hline & & & & & & & & & \\
\hline
\end{tabular}

Communicational ethics (CE), Climatic ethics (CLE), Organizational decision -making ethics (ODME), Behavioral ethics (BE), performance (P), Affective commitment (AC), Continuous commitment (CC), Normative commitment (NC)

H 1: There is a significant relationship between managers' ethical leadership approaches and employees' performance

When able 2 is overviewed, a significant low-level positive relationship between communicational ethics, climatic ethic, and organizational decision making ethics and employees' performance $(\mathrm{r}=0.329$; $\mathrm{r}=0.282 ; \mathrm{r}=0.170 ; \mathrm{p}<0.001)$. A relationship has not been observed between behavioral ethics and performance $(\mathrm{r}=.039 ; \mathrm{p}>.001)$. 
$H$ 2: There is a significant relationship between managers' ethical leadership approaches and employees' organizational commitment

A significant positive low-level relationship was observed between communicative ethics and affective commitment $(\mathrm{r}=0.188 ; \mathrm{p}<0.001)$; continuous commitment $\quad(\mathrm{r}=0.359 ; \mathrm{p}<0.001)$ and normative commitment $(\mathrm{r}=0.255 ; \mathrm{p}<0.001)$.

A significant positive low-level relationship was observed between climatic and affective commitments $(\mathrm{r}=0.343 ; \mathrm{p}<0.001)$ and normative commitment $(\mathrm{r}=0.359 ; \mathrm{p}<0.001)$. A significant relationship was not noted between climatic ethics and continuous commitment ( $\mathrm{r}=0.081 ; \mathrm{p}>0.05)$.

A positive low-level significant relationship was noted between ethics in organizational decisionmaking and affective commitment $(\mathrm{r}=0.310 ; \mathrm{p}<0.001)$ and normative commitment $(\mathrm{r}=0.370 ; \mathrm{p}<0.001)$. A significant relationship between organizational decision-making ethics and continuous commitment $(\mathrm{r}=0.015 ; \mathrm{p}>0.05)$

A significant low-level relationship was observed between behavioral and affective ethics ( $r=0.233$; $\mathrm{p}<0.001)$ and normative commitment $(\mathrm{r}=0.275$; $\mathrm{p}<0.001$ ). A significant relationship was not noted between behavioral ethics and continuous commitment $(\mathrm{r}=0.091 ; \mathrm{p}>0.05)$

\subsection{Regression Analysis Results}

The results of the regression analyses to specify the interaction effect of the variables are as follows;

H 3. There is a significant effect of managers' ethical leadership approaches on employees' performance.

The regression analysis result of $\mathrm{H} 3$ is revealed in Table 5. Regression efficiencies were tested through $\mathrm{t}$ statistics and ethical leadership approaches $(p<0,001)$ were found statistically meaningful in the regression equation explaining employees' performance.

Table 5. Effect of Managers' Ethical Leadership Approaches on Employees' Performance

\begin{tabular}{|c|c|c|c|c|c|}
\hline & & & $(\beta)$ & p-value & $\Delta \mathbf{R}^{2}$ \\
\hline Fixed () & & & 1,624 & $<.0001$ & \\
\hline $\begin{array}{l}\text { Ethical } \\
\text { Leadership }\end{array}$ & à & Performance & 653 & $<.0001$ & .272 \\
\hline
\end{tabular}

The regression model was found meaningful $(\mathrm{p}<0.001)$, efficiency $=0.272$,:regression efficiency

As in Table 5,the effect of managers' ethical leadership approaches on employees' performance rate is \%27.2. A single unit increase in ethical leadership approaches increases employees' performance 0.653 times. In other words, managers' ethical leadership approaches have a significant positive effect on employees' performance.

Performance $=1.624+0.653$ (Ethical leadership).

Table 6. The Effect of the Sub-Dimensions of Managers' Ethical Leadership Approaches on Employee Performance

\begin{tabular}{|c|c|c|c|c|c|}
\hline $\begin{array}{l}\text { Ethical } \\
\text { Leadership }\end{array}$ & & Performance & $(\beta)$ & p-value & $\Delta \mathbf{R}^{2}$ \\
\hline Fixed() & & & 1,243 & $<.0001$ & \multirow{5}{*}{.325} \\
\hline $\mathrm{CE}$ & à & Performance & .408 & $<.0001$ & \\
\hline CLE & à & Performance & .201 & $<.005$ & \\
\hline ODME & à & Performance & .027 & .698 & \\
\hline $\mathrm{BE}$ & à & Performance & .087 & .0060 & \\
\hline
\end{tabular}

The regression model was found meaningful $(\mathrm{p}<0.001)$, efficiency $=0.325$, : regression efficiency

The regression efficiencies were tested through $\mathrm{t}$ statistics and communicative ethics $(\mathrm{p}<0.001)$ and climatic ethics $(p<0.001)$, explaining employees' performance were found meaningful in regression equation. Behavioral ethics $(p=0.060)$ and Organizational decision-making ethics $(p=0.689)$ are not meaningful in explaining the model. A single-unit increase in communicative ethical approach increases organizational commitment 0.408 times. A single-unit increase in Climatic ethical approach increases organizational commitment 0.201 times. This indicates that communicative and climatic ethical approaches have a statistically positive and meaningful effect on organizational commitment. The multi-exploratory efficiency result showed that the exploratory percentage of the independent variables was $\left(R^{2}\right) 0.325$. The founding is as follows;

Performance $=1,243+0.408$ (Communicative ethics) + 0,201 (Climatic ethics) + 0,027 (Organizational decisionmaking ethics) +0.087 (Behavioral ethics)

H 4. Managers' ethical leadership approaches have a meaningful effect on employees' organizational commitments

The regression analysis result of $\mathrm{H} 4$ is revealed in Table 7. Regression efficiencies were tested through $\mathrm{t}$ statistics and ethical leadership approaches $(p<0,001)$ were found 
statistically meaningful in the regression equation explaining employees' organizational commitments.

Table 7. The Effect of Managers' Ethical Leadership Approaches on Employees' Organizational Commitment

\begin{tabular}{|l|l|l|c|c|c|}
\hline \multicolumn{2}{|c|}{} & $(\beta)$ & p-value & $\Delta \mathbf{R}^{2}$ \\
\hline $\begin{array}{l}\text { Fixed() } \\
\text { Ethical } \\
\text { Leadership }\end{array}$ & à & $\begin{array}{l}\text { Organizational } \\
\text { Commitment }\end{array}$ & 1,603 & $<.0001$ & \multirow{2}{*}{.49} \\
\cline { 1 - 4 }
\end{tabular}

The regression model was found meaningful ( $\mathrm{p}<0.001)$, efficiency $=0.249$, regression efficiency

The effect of managers' ethical leadership approaches on employees' organizational commitment was found around \%24.9. A single-unit increase in ethical leadership approaches increases employees' organizational commitment 0.437 times. There is a statistically positive and meaningful effect of ethical leadership approaches on organizational commitment. Organizational commitment $=1,603+0,473$ (Ethical leadership).

The results of the regression analysis to determine the effect of the sub-dimensions of managers' ethical leadership approacheson the sub-dimensions of organizational commitments are as in Table 8.

Table 8. The Effect of the Sub-Dimensions of Managers' Ethical Leadership Approaches on Affective Commitment

\begin{tabular}{|c|c|c|c|c|c|}
\hline $\begin{array}{l}\text { Ethical } \\
\text { Leadership }\end{array}$ & & $\begin{array}{l}\text { Organizational } \\
\text { Commitment }\end{array}$ & $(\beta)$ & p.value & $\Delta \mathbf{R}^{2}$ \\
\hline Fixed() & & & 1,572 & $<.0001$ & \multirow{5}{*}{.110} \\
\hline $\mathrm{CE}$ & à & AC & .100 & .401 & \\
\hline CLE & à & $\mathrm{AC}$ & .465 & $<.0001$ & \\
\hline ODME & à & AC & .073 & .551 & \\
\hline $\mathrm{BE}$ & à & AC & .139 & .087 & \\
\hline
\end{tabular}

The regression model was found meaningful $(\mathrm{p}<0.001)$, efficiency $=0.110$, : regression efficiency

The regression efficiencies were tested through $t$ statistics and Climatic ethics $(p<0,001)$ was found meaningful in the regression equation explaining affective commitment. A single-unit increase in Climatic ethics approaches increase affective commitment 0,465 times. Communicative ethics ( $p=0,401$ ), organizational decision-making ethics $(\mathrm{p}=0,551)$ and behavioral ethics $(p=0,087)$ were not found meaningful in the regression equation explaining affective commitment. At the end of multilinear regression analysis, the percentage of the exploratory efficiency of the independent variables model was $\left(R^{2}\right), 0.110$. The regression equation found meaningful is as follows;

Affective commitment $=1,572+0,100 \quad$ (Communicative ethics)+0,465 (Climatic ethics)+0,073 (Organizational decision-making ethics)+0,193 (Behavioral ethics)

Table 9. The Effect of the Sub-Dimensions of Managers' Ethical Leadership Approaches on Continuous Commitment

\begin{tabular}{|c|c|c|c|c|c|}
\hline $\begin{array}{l}\text { Ethical } \\
\text { Leadership }\end{array}$ & & $\begin{array}{l}\text { Organizational } \\
\text { Commitment }\end{array}$ & $(\beta)$ & p.value & $\Delta \mathbf{R}^{2}$ \\
\hline Sabit () & & & 1,537 & .023 & \multirow{5}{*}{.045} \\
\hline $\mathrm{CE}$ & à & $\mathrm{CC}$ & .681 & $<.0001$ & \\
\hline VLE & à & $\mathrm{CC}$ & .231 & .212 & \\
\hline ODME & à & $\mathrm{CC}$ & .026 & .885 & \\
\hline $\mathrm{BE}$ & à & CC & .189 & .112 & \\
\hline
\end{tabular}

The regression model was found meaningful $(p<0.001)$, efficiency $=0.045$, regression efficiency

The regression efficiencies were tested through $t$ statistics and communicative ethics $(p<0.001)$ was found meaningful in the regression model explaining continuous commitment. However, Climatic ethics $(p=0,212)$, organizational decision-making ethics $(p=0,885)$, and behavioral ethics $(p=0,112)$ were not found statistically meaningful in the regression equation explaining continuous commitment. A singleunit increase in communicative approach ethics raises continuous commitment 0,681 times. The multilinear regression analysis revealed the exploratory efficiency of independent variables as $\left(R^{2}\right) 0,045$. The meaningful regression equation is as follows;

Continuous commitment $=1,537+0,681$ (Communicative ethics $)+0,231$ (Climatic ethics) $+0,026$ (Organizational decision-making ethics) $+0,189$ (Behavioral ethics)

Tablo 10. The Effect of the Sub-Dimensions of Managers' Ethical Leadership Approaches on Normative Commitment

\begin{tabular}{|c|c|c|c|c|c|}
\hline $\begin{array}{l}\text { Ethical } \\
\text { Leadership }\end{array}$ & & $\begin{array}{l}\text { Organizational } \\
\text { Commitment }\end{array}$ & $(\beta)$ & p.value & $\Delta \mathbf{R}^{2}$ \\
\hline Fixed() & & & 1,210 & .000 & \multirow{5}{*}{.290} \\
\hline $\mathrm{CE}$ & à & $\mathrm{NC}$ & .048 & .497 & \\
\hline CLE & à & NC & .174 & .020 & \\
\hline ODME & à & $\mathrm{NC}$ & .382 & .000 & \\
\hline $\mathrm{BE}$ & à & $\mathrm{NC}$ & .029 & .545 & \\
\hline
\end{tabular}


The regression model was found meaningful $(\mathrm{p}<0.001)$, efficiency $=0.290$, : regression efficiency

The regression efficiencies were tested through $t$ statistics and organizational decision-making ethics $(p<0.001)$ was found meaningful in the regression model explaining normative commitment. However, Communicative ethics ( $p=0,497)$ and behavioral ethics $(p=0,545)$ were not found statistically meaningful in the regression equation explaining communicative commitment. A single-unit increase in climatic ethics approach ethics raises normative commitment 0,174 times. A single-unit increase in organizational decision-making ethics approach ethics raises normative commitment 0.382 times. The multilinear regression analysis revealed the exploratory efficiency of independent variables as $\left(R^{2}\right)$ 0,290. The meaningful regression equation is as follows;

Normative commitment $=1,210+0,048$ (Communicative ethics) $+0,174$ (Climatic ethics) $+0,382$ (Organizational decision-making ethics)+0,029 (Behavioral ethics)

\subsection{The results in Structural Equity Modelling (SEM)}

The findings related to the effect of managers' ethical leadership approaches on employees' performance and the role of organizational commitment are explained in this part.

H 5 Organizational commitment has a mediating role on the managers' ethical leadership approaches on employees' performance.

The effect of organizational commitment on the relationship between ethical leadership approaches and performance. Therefore, in order to evaluate the concepts reached in factor analysis, mathematical averages of the scores were taken. This enabled obtaining the scores from each participant in Ethical leadership, performance, and Organizational commitment, these were tested through Structural Equity Model and the meditative factor of organizational commitment was tested. The analysis was repeated to determine how the intermediary variable affected the model, In this process, firstly the effect of ethical leadership approaches on employees' performance without considering the intermediary variable (organizational commitment).

Table 11. The direct effect of managers' ethical leadership approaches on employees' performance

\begin{tabular}{|c|c|c|c|c|}
\hline \multicolumn{3}{|c|}{ Relationships } & Estimate & p. value \\
\hline Performance & $\leftarrow$ & $\begin{array}{l}\text { Ethical } \\
\text { Leadership }\end{array}$ & .522 & .000 \\
\hline
\end{tabular}

When the effect of ethical leadership approaches on employees' is overview without the intermediary variable (Organizational Commitment), it can be observed that the independent variable has a significant effect on the dependent variable $(R=0.522 ; p<0.000)$. In order to specify the effect of intermediary variable on the model the analysis was done again with the intermediary variable. The results showed that ethical leadership approaches affected employees' performance $(\mathrm{R}=.512 ; \mathrm{p}<0.05)$. The results are as in Table 12 .

Table 12. $\mathrm{T}$ he Intermediary Role of Organizational Commitment in the Effect of Managers' Ethical Leadership Approaches on Employees' Performance

\begin{tabular}{|c|c|c|c|c|c|c|c|}
\hline \multicolumn{5}{|c|}{ Relationships } & \multirow{2}{*}{$\begin{array}{c}\begin{array}{c}\text { Mediator without } \\
\text { variable (Direct } \\
\text { effect) }\end{array} \\
.522(.000)\end{array}$} & \multirow{2}{*}{$\begin{array}{c}\begin{array}{c}\text { Mediator with } \\
\text { variable (Total } \\
\text { effect) }\end{array} \\
.512(.000)\end{array}$} & \multirow{2}{*}{\begin{tabular}{|l}
$\begin{array}{c}\text { Indirect } \\
\text { effect }\end{array}$ \\
$.01(.780)$
\end{tabular}} \\
\hline Performance & $\leftarrow$ & $\begin{array}{c}\text { Organizational } \\
\text { Commitment }\end{array}$ & $\leftarrow$ & $\begin{array}{c}\text { Ethical } \\
\text { Leadership }\end{array}$ & & & \\
\hline
\end{tabular}

${ }^{*}(p<0,05)$.

It has been observed that the calculated estimation has fallen from 0.522 to 0.511 and this indicates the organizational commitment as a partial effect on employees' performance in terms of ethical leadership approaches. The efficiency in the direct effect should be variable, but when it is included in the model, its value should fall or the 
direct relationship should have no meaning. In order to talk about full or partly effect, it is necessary to examine the $\beta$ efficiency and $p$ value. When we include the intermediary variable into the model, if the inter variable relationships are not meaningful, it is fully mediating, if the relationship weakens, the effect is partly mediatory. In order to determine the statistical meaningfulness of mediation role, a test was given again and the result obtained was $(R=0,01 ; p>0.05)$. This indicates a strong intermediary effect of organizational commitment on employees' performance in terms of ethical leadership approaches.

\section{DISCUSSION}

Health professionals (managers, doctors, clerks, servants and administrative staff) in private health institutions were the target population of this research. The samplings were composed of 362 health professionals who completed the questionnaires as instructed. $\% 48.8$ of the target population were reached, the majority of whom were female (\%61.3), between the ages of 30-49 (\%70.4). \%31.8 was doctors and nurses (\%33.6). \%35.9 with post-graduate degrees, with 1-10 years service in the institution (\%76.2).

A correlation analysis to specify the relationship among variables, a multi-regression analysis and method analyses were done to specify interaction. Climatic ethics sub-dimension had the highest correlation value as 0.609 . When the relationship between managers' ethical leadership approach dimensions and employees' performance was overviewed, a significant low-level positive difference was noted between communicative ethics, climatic ethics, and organizational decision-making ethics.A relationship between behavioral ethics and performance was not noted. The findings of this research are parellel to the findings by Cummings \& Schwab, (1973); Avolio \& Bass,(1995); Ferrel, Maignan \& Loe, (1999); Zhu, Chew \& Spangler,(2005); Piccolo, Breenbaum, Hartog \& Folger, (2010); Sikander, (2010); Fulmer, (2004); Aksoy, (2012); Öztürk, (2016); Onan, (2017).In general, it can be said that there is a significant low-level relationship between managers' ethical leadership approaches and employees' performance. This result supports H1.

When the regression results in the effect of managers' ethical leadership approach dimensions on employees' performance are overviewed, it can be noted that communication and climatic ethics have a statistically significant positive effect on employee' performance. A single-unit rise in communicative ethical approach increases organizational commitment 0.201 times. In the regression model explaining organizational commitment in behavioral ethics and organizational decision-making ethics a meaningful difference was not noted. The overall effect of managers' ethical leadership approaches on employees' performance was found around \% 27.2. A single-unit rise in ethical leadership approaches causes a 0.653 increase in employees' performance. Thus, managers' ethical leadership approaches on employees' performance has a statistically meaningful and positive effect. This result supports H3.When the effects of managers' ethical leadership approach dimensions on organizational commitment are examined it is observed that;

- Climatic ethics approach has a positive effect on organizational commitment dimensions. A singleunit rise in climatic ethics approaches increases affectional commitment 0.465 times. Climatic ethics was not found statistically meaningful in the regression equation expressing ethics and behavioral ethics in organizational decisionmaking.

- The regression model explaining communicative ethics and continuous commitment was found statistically meaningful. A single-unit rise in communicative ethics approach increases continuous commitment 0.681 times. Climatic ethics was not found statistically meaningful in regression equation explaining behavioral ethics continuous commitment in organizational decision-making.

- The regression model explaining ethical normative commitment in climatic ethics and decisionmaking was found statistically meaningful. In the regression equation explaining communicative ethics and behavioral ethics normative commitment was not found statistically meaningful. A singleunit rise in climatic ethics approach increases normative commitment 0.174 times. A single-unit rise in organizational decision-making increases normative commitment 0.382 times.

In general, the regression equity explaining employees' organizational commitment was found statistically meaningful. The effect of managers' ethical leadership approaches on employees' organizational commitment is around \%24.9. A single-unit rise in ethical leadership approaches increases employees' organizational commitments 0.473 times. Managers' ethical leadership approaches have a statistically positive and meaningful effect on organizational commitment. 
Similar findings were observed in studies by Calson, (2005); Hunt, Wood \& Chonco, (1998); and Uğurlu, (2009). This result supports H 4.

In specifying the effect of the intermediary role of organizational commitment in terms of the effect of managers' ethical leadership approaches on employees' performance, the Structural Equity Model SEM) was used. It has been observed that ethical managerial approaches directly influence employees' performance. When the effects of organizational commitment dimensions on employees' performance, an effect at maximum level was noted. Continuous commitment does not have any effect on employees' performance. Despite a low-level effect of normative commitment sub-dimension, it does not significantly affect employees' performance. In the light of this information, it is observed that in terms of the effect of organizational commitment concept on employees' performance only affective commitment sub-dimension has a meaning. When the efficiency is included in the variable model, the direct connection is meaningless. At this point, in order to talk about a total or partly effect, the $p$ meaningfulness value and $\beta$ efficiency was reconsidered. When the mediator is included in the variable model, and the connection between dependent and independent variables is not meaningful a total mediator effect is at stake, if the connection drops, a partly mediator is at stake. In order to examine the mediatory role in statistically meaningfulness, the test was repeated and it was observed that organizational commitment had a total mediatory role in terms of the effect of managers' ethical leadership approaches on employees' performance. This result support H5. Another important finding in this research, carried out in private health institutions, is that, employee' continuous and organizational commitments were affected at a high level. Ethical leadership approaches did not have a significant effect on continuous commitment. The reason for this is that workers, for certain reasons, find themselves obliged to be present at the organization. Therefore, the level of relationship among workers is not positive. Ethical leadership approaches has a positive effect on normative commitment, but it is not high as it is in the leadership type. Employees' in the continuous commitment dimension think that they spend time and effort for their organization and as a result of such a thought they feel obliged to stay in the organization because they have the fear that they may not get a better job when they leave the organization. In terms of normative commitment, they see it a duty to stay with the organization thinking that they were employed when they were hopeless. The results obtained from this research show those managers' exhibiting ethical leadership approaches affected employees' commitment and performance. It has been observed that leaders being close to workers, increase their moral and motivation and as a result their commitment to the organization.

Leaders can lead the community, organizations and individuals by being interacted with them. Leaders' behavioral models may differ from one to the other. Man power, the basic of production, is greatly affected by leaders' attitude and behaviors. This determines their wish to work and reflects to their organizational commitment positively or negatively. Organizations which do not invest for their staff may face low organizational commitment, non-productivity and low performance.

\section{CONCLUSION}

In this research it was aimed, mainly in health sectors, to specify the effects of managers' ethical leadership approaches on employees' performance and organizational commitment and its mediatory role in this effect. In this regard, a research model, in which for ethical leadership behaviors a dependent variable and for employees' performance and organizational commitment a dependent variable model was referred to. Following the specification of a connection between perceived ethical leadership behaviors and employees' performance, an answer to the amount of effect of organizational commitment was seemed. At the end of the analyses done, positive significant relationships were determined between ethical leadership approaches and organizational commitment and employees' performance.As a result, it was observed that ethical leadership approaches affected employees' performance and that organizational commitment had an intermediator role in this issue. It has also been observed that these findings match the ones in previous studies done. The research was carried out in a holistic model, including the relationships and effects among variables and it is hoped that it will contribute to the literature. Because the research was limited with the sampling group, utmost care should be given when commenting on it and generalizing. As in every organization, the importance of an ethical leadership model is emphasized to prevent mobbing approaches towards the workers and commercial immorality. 


\section{REFERENCES}

- AKTAŞ, E. (2010). Performans Değerlendirme Sistemlerinin Örgütsel Adalet Algısı Üzerine Etkisi. Unpublished Master's Thesis, Dokuz Eylül University Institute of Social Sciences, İzmir.

- ALLEN, N.\&MEYER, J.P. (1990). The Measurement and Antecedents Of Affective, Continuance and Normative Commitment to the Organization. Journal Of Occupational Psychology, 63(1), 123-148.

- ATABAY R. \& IYYIGÜN, Ö.N. (2015). Güncel Yaklaşımlar Işı̆̆̆ıda Etik. Istanbul: Beta Basım Yayın.

- AVOLIO, B.J. \& BASS, B.M, (1995). Individualised Consideration Viewed At Multiple Levels Of Analysis: A Multi-Level Framework For Examining The Diffusion Of Transformational Leadership. Leadership Quarterly, 6.

- AYDOĞAN Z. \& FERHAN, A.Z. (2004). Örgüt Kültürü ve İklimi. Gazi Üniversitesi Ticaret ve Turizm Eğitim Fakültesi Dergisi, 2, 203-215.

- BENNIS, W. (2009). On Becoming A Leader. New York: Basic Books.

- BILGEN, A. (2014). Çalışanların Etik Liderlik Ve Etik Iklim Algilamalarının Örgütsel Bağlllıklarına Etkisi: Özel ve Kamu Sektöründe Karşılaştırmalı Bir Uygulama. Unpublished Master Thesis. İstanbul: Bahçeşehir University Institute of Social Sciences.

- BOSE, S., OLIVERAS, E., \& EDSON, W.N. (2001). How Can SelfAssessment improve the quality Of Healthcare. Quality Assurance Project. 2(4), 1-27.

- BROWN, M. E., TREVIÑO L.K., \& HARRISON, D.A. (2005). Ethical Leadership: A Social Learning Perspective for construct Development and Testing. Organizational Behaviorand Human Decision Processes, 97, 117-134.

- CARLSON, S.C. (2005). Ethical Leadership: Influences Of Ethical Climate, Perceived Organizational Support, And Perceived Leader Integrity. Un published Doctorate Thesis, Nova Southeastern University.

- CHURIN, A. (2006). Personel Güçlendirme Ve Bireysel Performans İlişkisi Üzerine Bir Araştırma. Unpublished Doctorate Thesis, Istanbul University Institute of Social Sciences, İstanbul.

- CIULLA, J. B. (1996). Ethics and Critical Thinking in Leadership Education. The Journal of Leadership Studies. 3(3), 110-119.

- CIULlA, J.B. (2014). Ethics, The Heart of Leadership. Abc-Clıo Llc, California.

- COHEN, A.R. (1992). Effective Behavior in Organizations. USA: Irwininc.

- CUMMINGS L. L. (1973). Schwab D.P. Performance In Organizations: Determinants And Apprasial. Glenvies Iii: Scott, Foresman.

- DOUGLAS, H. (2005). Ethical Leadership Is Not Optional: How Lpps Can Help. International Journal Of Scholarly Academic Intellectual Diversity, 8(1), 1-5.

- FERRELl, O.C., MAIGNAN, I. \& LOE, T.A. (1999). Corporate Ethics + Citizenship $=$ Competitive Advantage. Successful Business Through Successful Ethics Programs Proceedings, Center For Ethics, University of Tampa, March 19.

- FLETCHER, J. (1966). Situation Ethics: The New Morality. Westminster John Knoxpress, Loiusville Kentucky.

- FULMER, R.F. (2005). The Challenge of Ethical leadership. Organizational Dynamics, 33(3), 307-317.

- HARMAN, G. (1999). Moral Philosophy Meets Social Psychology: Virtue Ethics and The Fundamental Attribution Error. Proceedings of The Aristotelian Society. 99, 315-331.

- HARTLinE, M. D. MAXHAM III, J.G. \& MCKEE, D.O. (2000). Corridors of Influence in the Dissemination of Customer-Oriented Strategy Customer Contact Service Employees. Journal of Marketing, 64(2), 35-50.

- HELD, V. (2006). The Ethics of Care: Personal, Political and Global. New York: Oxford University Press Inc.
- KATERBERG, R. (1983). An Examination of Level and Direction of Effort and Job Performance. Academy of Management Journal, 26(2), 250 .

- KILINÇ, A.Ç. (2010). Okul Yöneticilerinin Etik Liderlik Davranışları Gösterme Düzeyleri Ile Öğretmenlerin Yaşadıkları Örgütsel Güven ve Yildırma Arasındaki İlişki. Unpublished Master's Thesis, Ankara University Institute of Educational Sciences, Ankara.

- MATHIEU J.E. \& ZAJAC, D.M. (1990). A Review and MetaAnalysis of The antecedents, Correlates, and Consequences of Organizational Commitment. Psychological Bulletin, 108(2), 171-194.

- MAYER, D.M. \& AQUINO, K., GREENBAUM, R.L. \& KUENZI, M., (2012). Who Displays Ethical Leadership, and Why Does It Matter? An Examination of Antecedents and Consequences of Ethical leadership. Academy of Management Journal, 55(1), 151-171.

- MAYER, D.M., KUENZI, M., GREENBAUM R., BARDES, M. \& SALVADOR R.B. (2009). How Low Does Ethical Leadership Flow? Test of A Trickle - Down Model. Organizational Behavior and Human Decision Processes, 108(1), 1-13.

- MEŞE, G. (2007). Endüstri ve Örgüt Psikolojisinde Örgütsel Bağlılığın Anlamı.Tarık SOLMUŞ (Ed.), Endüstriyel Klinik Psikoloji ve Insan Kaynakları Yönetimi: Kuramdan Uygulamaya İş Yaşamında Psikoloji. İstanbul: Beta Yayınları, 239-260.

- MEYER, J.P. \& ALLEN, N.J. (1997). Commitment in the Workplace, Theory, Research and Application. London: Sage Publications Inc.

- MEYER, J.P. \& ALLEN, N.J. (1991). A. Three-Component Conceptualization of Organizational Commitment. Human Resource Management Review, 1(19), 61-89.

- MIHELIC, K.K., LIPICNIK, B. \& TEKAVCIC, M. (2010). Ethical Leadership. International Journal of Management $\mathcal{E}$ Information Systems, 14(5), 31-42.

- O'REILly, C.A. \& CHATMAN, J. (1986). Organizational Commitment And Psychological Attachment: The Effects Of Compliance, Identification, and Internalization on Prosocial Behavior. Journal of Applied Psychology, 71(3), 492-499.

- PICCOLO, R. F., GREENBAUM, R.H., HARTOG D.N. \& FOLGER, R. (2010). The Relationship Between Ethical Leadership and Core Job Characteristics. Journal of Organizational Behavior. 31(2), 259-278.

- FREEMAN R.E. \& STEWARD, L. (2006). Developing Ethical Leadership. Business Round Table Institute for Corporate Ethics, $1-14$.

- RAZ, J. (1994). Ethics in The Public Domain. Oxford: Clarend on Press.

- ROBBINS, S. P. (2002). Organizational Behaviour, 10th Edition, USA: Prentice Hall.

- SEVIM, E. (2016). Teknoloji Tabanl Kontrol Sistemlerinin Personelin Bireysel Performans, İş Tatmini ve Motivasyon Üzerindeki Etkileri: Taşımacılık Sektöründe Bir Uygulama, Published Master Thesis, Okan University Institute of Social Sciences. İstanbul.

- SHIELDS J. (2007). Managing Employee Performance and Reward Concepts, Practices and Strategies. New York: Cambridge University Press.

- SIGLER, T. H. \& CO M. (200). Pearson Creating an Empowering Culture: Examining the Relationship Between Organizational Culture and Perceptions of Empowerment. Journal of Quality Management, 5(1), 27-52.

- SIKANDER, W. (2010). Impact of Leadership Styles on Employee's Performance and Their Health in SME Sector. Superior University, Master Thesis Mba, Unpublication.

- TETT R.P. \& MEYER, J.P., (1993). Job Satisfaction, Organizational Commitment, Turn Over Intention, And Turnover: Path Analyses Based on Meta-Analytic Findings. Personnel Psychology. 46(2), 259293.

- TOOR S.U.R. \& OFORI, G. (2009). Ethical Leadership: Examining the Relationships with Full Range Leadership Model. Employee 
Outcomes, and Organizational Culture. Journal of Business Ethics. 90 (4), 533-547.

- VAROL, M, (1989). Örgüt Kültürü ve Örgüt İklimi, Journal of Ankara University. 44(1), 195-222.

- VELASQUEZ, M.G, (2002). Business Ethics: Concepts and Cases. 111, Prenticehall, Upper Saddle River, $\mathrm{Nj}$.

- WAllaCE, J.A, (1995). Organizational and Professional Commitment in Professional and Nonprofessional Organizations. Administrative Science Quarterly, 40, 228-256.

- WASTI, S. A. \& MEYER, A. (2000). Üç Boyutlu Örgütsel Bağlılık Ölçeğinin Geçerlilik Ve Güvenirlilik Analizi. 8. Ulusal Yönetim Ve Organizasyon Kongresi Bildirileri, 401-410.

- WATSON, T, (2010). Leader Ethics and Organizational Commitment. Mid-Atlantic Leadership Scholars Forum, 3(1): 16-26.

- YILDIZ, B. (2016). Mesleki ve Teknik Anadolu Liseleri Okul Müdürlerinin Etik Liderlik Davranışları Gösterme Düzeylerinin Incelenmesi (Bursa Ili Gemlik İlçesi Örneği). Unpublished Master's Thesis, Yeditepe University Institute of Educational Sciences, İstanbul.

- ZHU, W., CHEW, I. \& SPANGLER, W. (2005). Ceo Transformational Leadership And Organizational Outcomes: The Mediating Role of Human-Capital-Enhancing Human Resources Management. The Leadership Quarterly, 16.

- ZHU, W., MAY, D. M., AVOLIO, B. J. (2004). The Impact of Ethical Leadership Behavior on Employee Outcomes: The Roles of Psychological Empowerment and Authenticity. Journal of Leadership E Organizational Studies, 11 (1), 16- 28. 